\title{
COGENERATION PLANT ON BIOMASS - CASE STUDY
}

\author{
A. ENESCU, E. DIACONU \\ University Valahia, Targoviste, Romania \\ E-mail: enescu_alex17@yahoo.com; emy_diaconu@yahoo.com
}

\begin{abstract}
The concept of cogeneration defines the simultaneous production with the same installation of electric and thermal energy (in the form of hot water or steam). Highefficiency cogeneration implies that cogeneration production should ensure primary energy savings of at least $10 \%$ compared to the reference values of separate production of electricity and heat. This paper presents the process of functioning of a cogeneration plant, operating in the Suceava county, Romania, referring to the actual values regarding the consumption and the proportions of the raw material on the one hand and the energy produced on the other. It also describes the entire production process as well as the impact on the environment, the social and economic aspects of the implementation of such a project.
\end{abstract}

Keywords: cogeneration, power plant, biogas, cogeneration modules, installed power, electrical capacity.

\section{INTRODUCTION}

The extremely dynamic evolution of human society has influenced the environment. Nowadays, new records are being made on the Earth in terms of climate change, often being radical and even damaging, determining heavier living conditions, and having a negative impact on the environment [1], [2].

In this context, concepts such as sustainable development, environmental protection, the use of renewable energy sources have become essential and a global necessity, becoming a permanent concern for all states.

At European Union level, environmental concerns, especially negative environmental impacts, have steadily increased over the last decades. Environmental protection is an area of major concern, with a particular focus on integrating the priorities of this area into all sectors of economic policies [3].

Promoting the production of electricity from renewable energy sources is an imperative of the current period motivated by: environmental protection, increased energy independence from imports through diversification of sources of energy supply as well as economic and social cohesion reasons.

European Parliament and Council Directive 2001/77/EC on the promotion of electricity produced from renewable energy sources in the internal market is the first concrete action made by the European Union to meet its greenhouse gas emission reduction commitments, to which it had committed by ratifying the Kyoto Protocol [4].

Romania was one of the first candidate countries to the European Union to transpose into its legislation the provisions of Directive 2001/77/EC (GD No. 443/2003, as amended by GD 958/2005). Subsequently, Law $220 / 2008$ on the establishment of a system for the promotion of energy production from renewable energy sources was promulgated, with the subsequent amendments and completions, setting the level of the national targets for the share of electricity produced from renewable energy sources in terms of gross final consumption electricity for the years 2015 and 2020 of $35 \%$, respectively $38 \%$ [5].

In this respect, the Romanian Government has implemented the provisions of the European Directive 2001/77/EC on the promotion of electricity production from renewable energy sources, adapting Romania's Energy Policy in this respect. Thus, Law 220/2008, with subsequent amendments and additions, on the promotion of renewable energy sources was adopted through the application of the Green Certificates support scheme. This scheme supports the implementation of renewable electricity generation projects by granting Green Certificates to electricity generators based on the technology used to produce electricity from renewable sources [6].

This article presents the production process, the energy parameters and the environmental impact of a cogeneration plant in Romania [7]. The investment was made for the energy recovery of renewable energy of biomass produced in agriculture and related industries used for electricity generation. Biomass represents biodegradable fractions obtained from agricultural and non-agricultural crops waste from agriculture, horticulture, aquaculture, fishing and from food preparation and processing. The Moara cogeneration plant uses a combination of biomass types - silo maize and animal manure. By capitalizing these renewable resources in biogas plant digestors, biogas is being fed into two Generator Jenbacher cogeneration engines that simultaneously produce electricity and heat.

\section{DESCRIPTION OF COGENERATION PLANT}

The Moara Project - Suceava County is the largest at present in Romania, for this kind of technology and biomass used. It is a project initiated and developed by TEB Project One, with TEB Energy Business SA as a major associate. The total value of the investment is approximately EUR 6,300,000 and was supported by associate contributions and bank financing.

The steps for obtaining the permits and authorizations were started in the second semester of 2012 and the construction works began in April 2013 with the aim of 
producing renewable energy (electric and thermal) in cogeneration.

Completion of the construction works was carried out in December 2013 and the commissioning of the cogeneration plant (the actual supply of electricity to the NPS) took place in early March 2014.

Moara Cogeneration Plant is located in Suceava County, Moara village, Vornicenii Mici village.

The plant is equipped with two GE Jenbacher - JMS 420 GS - B.LC cogeneration engines operating on biogas [8]. The installed power of the plant is: $2,974 \mathrm{MW}$ el (2x1,487 MW) and 2,944 MWth (2x1472 MW), with a total efficiency of $83,9 \%$. The engine fuel is biogas from anaerobic fermentation of energy crops (fodder corn) and agricultural waste (livestock manure). The plant is located on 29500 square meters of land, with a biogas production capacity of $2 \mathrm{MW} / \mathrm{h}$ and the total installed electrical capacity of approx. $3 \mathrm{MW} / \mathrm{h}$.

The biogas plant operates continuously for 365 days a year, and the fermentation process can only be stopped in exceptional circumstances. Biogas produced during the night accumulates in the gas buffer tank. The two cogeneration engines produce electrical and thermal energy for 16 hours a day, between 7:00 and 23:00, with a maximum biogas consumption of $1600 \mathrm{~m} 3$ / hour.

The raw material used is composed of:

- Energy plant - silo maize (32\% SU) - approximately 36,200 tonnes/year $(96 \%)$;

- Cattle manure (18-22\% SU) - about 4,000 tonnes/year $(4 \%)$.

To produce $1 \mathrm{MW}$ of electricity for 8200 hours per year, an approximate amount of biomass is required, as shown in Table 1, below:

Table 1. Biomass type and the amount needed for $1 \mathrm{MW}$ of electricity

\begin{tabular}{|c|c|c|c|}
\hline Biomass type & $\begin{array}{c}\text { Amount } \\
{[\mathrm{t}]}\end{array}$ & $\begin{array}{c}\text { Area } \\
\text { cultivated } \\
{[\mathrm{ha}]}\end{array}$ & $\begin{array}{c}\text { Nr. of } \\
\text { animals/birds }\end{array}$ \\
\hline $\begin{array}{c}\text { High yield } \\
\text { corn silos }\end{array}$ & 19000 & $350-450$ & - \\
\hline $\begin{array}{c}\text { Manuare } \\
\text { from cattle or } \\
\text { birds }\end{array}$ & 51500 & - & 5000 \\
\hline $\begin{array}{c}\text { Organic } \\
\text { household } \\
\text { waste }\end{array}$ & 40000 & - & - \\
\hline
\end{tabular}

Besides the general advantages of using renewable energy sources, biogas has several specific advantages:

- It leads to job growth and rural development, approx. $50 \%$ of the investment is local.

- Supports the development of the agricultural sector. Local growers can conclude contracts/partnerships to secure the sale of long-term corn production.
- The solid part of digestate resulting from biogas plants is an excellent fertilizer for agriculture.

- Neutralizes the organic part of domestic wastes or animal manure.

- Predictable energy source compared to other sources of renewable energy (wind, solar).

\subsection{The main equipment and process of biogas and power generation}

The "Moara" cogeneration plant has two components (Figure 1):

1. The biogas plant;

2. A high-efficiency cogeneration power plant.

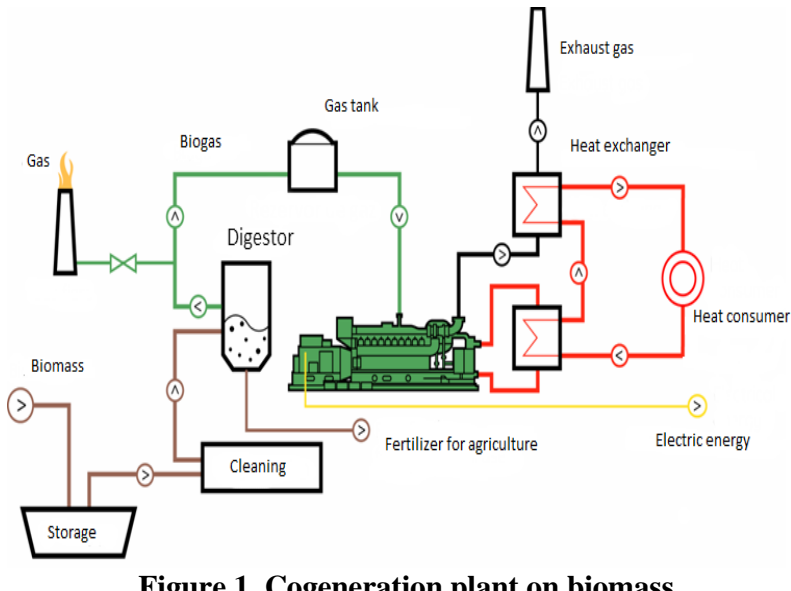

Figure 1. Cogeneration plant on biomass

\subsection{The biogas plant}

The main components of the biogas plant provided by UTS Biogastechnik GmbH are:

- Two feeding bunkers.

- Two solid-fuel feeders, each with a capacity of approx. $65 \mathrm{~m}^{3}$.

- The central part of the plant consists of two fermentation reactors called "HELIOS". They are heated and thermally insulated, each with a volume of approx. $3393 \mathrm{~m}^{3}$.

- A post-fermentation tank with a capacity of approx. $3393 \mathrm{~m}^{3}$.

Above the fermenters, a membrane roof is mounted. Inside, electric mixers are installed, and in each fermenter (digestor), a solid biomass feed is placed on the side.

- A separator.

- An external gas storage tank with a capacity of about 5000 cubic meters.

- A reservoir for collecting liquid waste from tanks.

- A gas burner.

- Two lagoons for storage of the liquid digestate resulting from the separation of solids after fermentation.

The biomass fermentation load is made from solid biomass bunkers through the two feeders using conveyor belts. The bunkers are filled twice a day by station staff with a dude. Quantitative and qualitative filling with substrate material is automated, as is the whole process of biogas production. 
Inside the fermenters (Figure 2), biomass is mixed continuously with mixers to homogenize and ferment. This is transferred between the two fermenters utilizing a pump to equalize the production of each, and after approximately one cycle of 60 days it is transferred to the postfermentator, and from there it will be removed by the separator.

The gas resulting from the fermentation is transferred via pipelines from each fermenter and postfermentor into the gas tank, from which the engines are fed. Before it gets to engines, biogas is subjected to desulphurization, cooling and water removal processes.

Upon completion of the fermentation process, the biomass is transferred from the postfermentator to the separator. This machine is designed to separate the liquid part from the solid part of the biomass. Some of the liquid quantity is redirected to the fermenters to achieve their dilution.

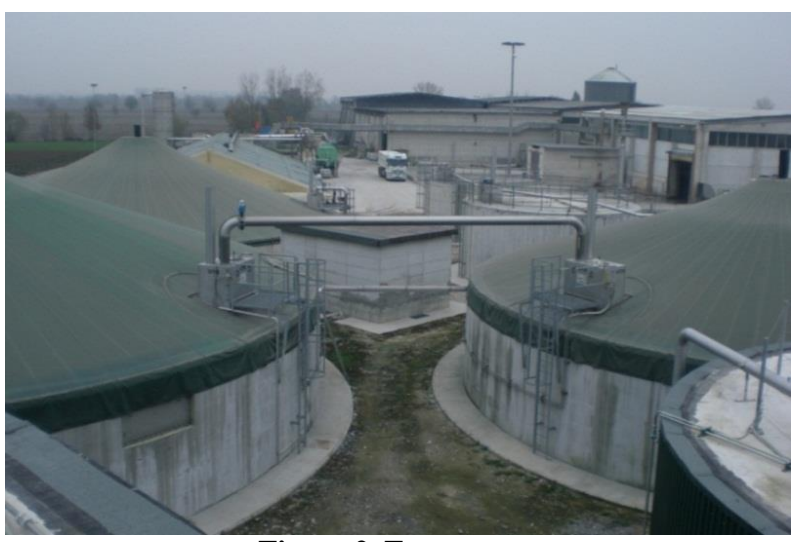

Figure 2. Fermenters

After separation, the remaining liquid is sent into 2 closed lagoons, from where it is taken up by vidanje and used as an agricultural dressing.

The solid digestate in the separator is taken over by specific equipment and is also used as agricultural fertilizer.

For the plant to operate at the projected parameters the whole process is coordinated by a computer that controls the commands according to the default dosages and the information received by the sensors situated on the technological flow.

\subsection{A power plant for high-efficiency cogeneration - Cogeneration modules}

The two cogeneration modules are GE Jenbacher Manufacturing and use as primary energy the biogas produced in fermenters producing simultaneously electric and thermal energy, fulfilling the conditions of highefficiency cogeneration

The main technical features of the modules are presented in the following Table 2:
Table 2. Technical specifications of cogeneration modules [8]

\begin{tabular}{|c|c|c|}
\hline Thermal engine type & \multicolumn{2}{|c|}{$\begin{array}{l}\text { JMS } 420 \text { GS-B.L } \\
\text { v. B } 25\end{array}$} \\
\hline Electrical power & 1.487 & $\mathrm{~kW}$ \\
\hline $\begin{array}{c}\text { Recoverable thermal power } \\
\left(180^{\circ} \mathrm{C} \text { at chimney) - tolerance }\right. \\
\pm 8 \%\end{array}$ & 1.472 & $\mathrm{kWt}$ \\
\hline $\begin{array}{l}\text { Fuel flow rate at } \mathrm{LCP}=4.5 \\
\mathrm{kWh} / \mathrm{Nm} 3-\text { tolerance } \pm 5 \%\end{array}$ & 784 & $\mathrm{Nm}^{3} / \mathrm{h}$ \\
\hline $\begin{array}{l}\text { Electrical efficiency - tolerance } \\
\pm 8 \%\end{array}$ & 42,2 & $\%$ \\
\hline $\begin{array}{c}\text { Thermal efficiency - tolerance } \pm \\
8 \%\end{array}$ & 41,7 & $\%$ \\
\hline $\begin{array}{c}\text { Total efficiency- tolerance } \pm \\
13 \%\end{array}$ & 83,9 & $\%$ \\
\hline Generator voltage & 0,4 & $\mathrm{kV}$ \\
\hline Frequency & 50 & $\mathrm{~Hz}$ \\
\hline Fuel gas pressure & $\begin{array}{l}120- \\
180\end{array}$ & mbar \\
\hline $\begin{array}{c}\text { Engine cooling water flow } \\
\text { temperature }\end{array}$ & 90 & ${ }^{\circ} \mathrm{C}$ \\
\hline $\begin{array}{l}\text { Engine cooling water flow back } \\
\text { temperature }\end{array}$ & 70 & ${ }^{\circ} \mathrm{C}$ \\
\hline Engine noise level & \multicolumn{2}{|c|}{$65 \mathrm{~dB}$ la $10 \mathrm{~m}$} \\
\hline
\end{tabular}

Cogeneration is the simultaneous generation of electrical (or mechanical) energy and heat energy from the same amount of fuel. The thermal energy produced is currently used at a rate of $6 \%$ in the biogas production process, and in the future, there will be solutions for its full use.

Heat recovery is made from the intercooler, lubricating oil and engine block generating hot water at $90^{\circ} \mathrm{C}$, and combustion gases with high temperature $\left(400-500^{\circ} \mathrm{C}\right)$ generate hot water.

GE Jenbacher Cogeneration Modules have high yields, reliability, and high availability. The capital repair of these motors is done after 60,000 hours of operation (approximately 7 to 8 years).

To maintain the continuous operation of the motors, the temperature inside the building in which they are located should be between $100-420^{\circ} \mathrm{C}$. The ventilation system must provide the above-specified temperature conditions, depending on the season. At the entry and exit points of the air ducts, noise reduction dampers are installed in such a way that the outside admissible noise level of 65 $\mathrm{dB}$ at 10 meters from the building is respected.

The combustion gases at the engine exit are passed through a catalyst where they have their Co and Nox concentrations reduced, then they reach the exhaust gas heat exchanger and then into the silencer.

A heating battery that will use the heat generated by the engine cooling circuit will be mounted on the ventilation system of the engine room. 
The technological process of producing electric and thermal energy from biogas from energy crops mixed with animal manure is carried out mainly in 3 distinct phases:

1. procurement, storage and preparation of the specific raw material from which the biogas for cogeneration groups is to be produced: the raw material (silo maize and animal manure) was ensured by concluding a 15-year contract with Lucosdiov Consulting SRL (one of the TEB Project One's associate) - local agricultural producer;

2. production by anaerobic fermentation of biogas takes place in two main fermenters and a secondary fermenter each having a maximum biogas storage capacity of $810 \mathrm{Nm}^{3}$, the biogas produced is stored in a tank with a capacity of $5,000 \mathrm{Nm}^{3}$;

3. combustion of biogas in the two JMS 420 GS GE Jenbacher cogeneration units simultaneously producing electric and thermal energy; engines have a 16 hour / 24-hour program.

The use of the electricity produced in the cogeneration groups is done:

a) one part for the biogas plant self-consumption;

b) the difference is delivered to the NPS.

At present, the use of thermal energy (in the form of hot water) takes place:

a) in the process of biogas production;

b) heating the plant's buildings;

c) in domestic hot water preparation.

Delivery of thermal energy as hot water to third parties is not taken into account at this time.

\section{NEED AND OPPORTUNITY OF THE INVESTMENT}

Company TEB PROJECT ONE S.R.L. has proposed to carry out such a project - Biomass Cogeneration Plant from Vornicenii Mici, with an installed capacity of 2,974 MW. From the biomass fermentation, biogas will be obtained, this being the fuel used by the two internal combustion engines with which the plant is equipped.

The above presented demonstrates the necessity and at the same time the opportunity to carry out this project.

The same conclusion was made by different countries from the UE, as it is demonstrated by the Figure 3.

The necessity of the project is mainly because the inhabitants of this planet now have to find the most viable and at the same time technically and economically feasible solutions to protect the environment and to reduce as much as possible the existing energy resources.

The necessity and opportunity of implementing the Central Cogeneration Project on Biomass Vornicenii Mici in Suceava County, with an installed capacity of $2,974 \mathrm{MW}$, is also due to the fact that this project contributes to the development of the disadvantaged areas in our country, by providing new jobs and at the same time improving the quality of life of the area's inhabitants.

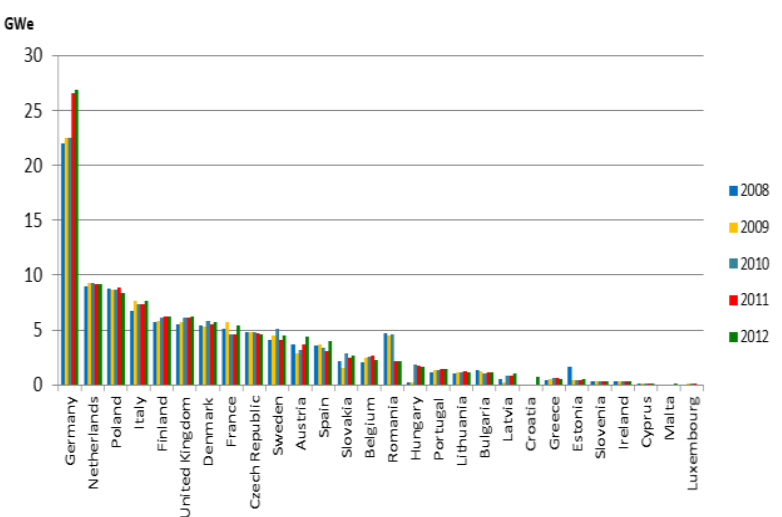

Figure 3. Evolution of the installed capacity of cogeneration plants per country 2008-2012 (source: Eurostat) [9], [10]

\section{CONCLUSIONS}

As a result of the above we can highlight some of the advantages offered by the project implementation:

- the project meets both the European and Romanian requirements and legislation related to the use and promotion of renewable resources at national and local level;

- locally assuring the electricity and heat demand and supplying electricity to NPS using renewable sources;

- introducing into the national energy balance of renewable energy resources using predictable technologies, necessary to increase the security of energy supply and to reduce the imports of primary energy resources;

- reducing the costs of energy utilities in the context of the increase of such expenses;

- the use of a primary energy resource type with lower procurement cost than natural gas;

- the amount of the investment is recovered in a short period of time compared to the depreciation period and the lifetime of the equipment.

- stimulate sustainable development at a local and regional level and create new jobs related to the processes of developing of renewable energy sources.

The efficacy of electricity generation and the overall efficiency of cogeneration plants has steadily increased over the years, while the efficiency of heat production has declined, reflecting changes in manufacturing processes such as growing demand for electricity and reducing the demand for thermal energy, as shown in Figure 4.

A cogeneration plant has almost twice the efficiency of plants that produce separate electrical and thermal energy. 


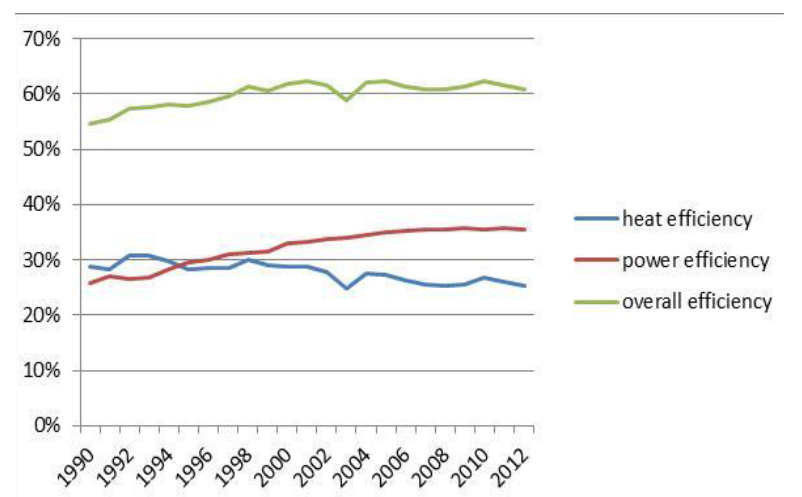

Figure 4. Heat/power efficiency vs. cogeneration efficiency [10]

\section{REFERENCES}

[1] H. Andrei, P.C. Andrei, Luminita Constantinescu, R. Beloiu, E. Cazacu, Marilena Stanculescu, Electrical Power Systems. In: Mahdavi Tabatabaei N., Jafari Aghbolaghi A., Bizon N., Blaabjerg F. (eds) Reactive Power Control in AC Power Systems. Power Systems, Springer, Cham, 2017.
[2] Lonnie G Thompson, Climate Change: The Evidence and Our Options, Behav Anal. 2010 Fall; 33(2): 153-170.

[3] The $7^{\text {th }}$ Environment Action Programme European Commission.

[4] European Parliament and Council Directive 2001/77/EC GD 443/2003 amended by GD $958 / 2005$.

[5] GD No. 443/2003, as amended by GD 958/2005.

[6] Law 220/2008 - establishment of a system for the promotion of energy production from renewable energy sources.

[7] COMMISSION DELEGATED REGULATION (EU) 2015/2402 of 12 October 2015 Revision of the harmonized yield reference values for separate production electricity and heat, in application of Directive 2012/27 / EU of the European Parliament and of the Council and repealing Commission Decision 2011/877 / EU.

[8] JMS 420 GS-N.L, Technical Specification.

[9] Eurostat.

[10] Energy policies of IEA countries, Country reports. 